\title{
FAILURE OF ANDROGEN TO AFFECT OVULATION AND PUBERTY IN SWINE
}

\author{
F. W. STRATMAN, N. L. FIRST AND ROLAND K. MEYER \\ University of Wisconsin, Madison*
}

(Received 15th Fuly 1968, accepted 28th October 1968)

\begin{abstract}
Summary. Female piglets injected subcutaneously with $25 \mathrm{mg} /$ day of testosterone propionate in $1 \mathrm{ml}$ of oil on Days 1, 3,5 and 7 postnatally, ovulated and formed corpora lutea, thus failing to prove that testosterone in the manner given affects ovulation and puberty.
\end{abstract}

The normal hypothalamic-hypophysial relationship can be altered in the rat by early postnatal treatment with either endogenous (Witschi \& Pfeiffer, 1935) or exogenous (Segal \& Johnson, 1959; Barraclough, 1961 ; Johnson, 1963; Swanson \& van der Werff ten Bosch, 1963) androgen. Lack of ovulation and subsequent corpora lutea formation characterize the effect of the treatment.

Whether the final differentiation of the hypothalamic-hypophysial axis has occurred before birth in female swine is not known. Large quantities of swine pituitary and hypothalamic tissue are readily available for extraction of hormones and the search for postulated chemotransmitters. If androgen sterilization is possible in swine, experiments could be designed to study the proposed mechanisms of pituitary control on a 'within species' basis. However, Zimbelman (1964) reported that testosterone injection within $48 \mathrm{hr}$ of birth did not alter average age of first oestrus in the pig.

The following experiment was completed in order to study the effect of exogenous testosterone, administered 3,5 and 7 days postnatally on the subsequent oestrous cycles and ovulation of the gilts.

Fifty crossbred (Yorkshire $\times$ Duroc and Duroc $\times$ Yorkshire) female piglets were randomly assigned at birth to two groups. The control group received no treatment. The other group received, subcutaneously, $25 \mathrm{mg}$ of testosterone propionate in $1 \mathrm{ml}$ of seasame oil ('Oreton'-Schering) per day on Days 1, 3, 5 and 7. Day of birth was considered as Day 1. The injection site was beneath the loose skin behind the front leg. Alternate sides were used for each successive injection.

The animals were weaned at 21 days of age and penned indoors in groups of approximately fifteen to twenty. Feed and water were available at all times. Protein and fibre content of the ration were reduced and increased, respectively, during the experiment, but were nutritionally adequate for the stages of growth. At approximately 150 days of age, four animals of the same treatment group were maintained together.

* Department of Meat and Animal Science Paper No. 519. 
Gilts were exposed to a boar and observed daily, from approximately 150 to 285 days of age, for signs of behavioural oestrus. All gilts exhibiting oestrus were killed and the ovaries were examined visually for ovulation, corpora lutea formation and evidence of corpora albicantia. As the experiment progressed, the results indicated that the control gilts were not reaching sexual puberty as would be normally expected. Therefore, after 285 days of age, the remaining control and treated gilts were killed.

Yates' modified Chi-square analysis was used to test the effect of androgen treatment on the variance in the number of gilts exhibiting oestrus.

The subcutaneous injection of $100 \mathrm{mg}$ of testosterone propionate postnatally did not significantly $(P>0.05)$ alter the hypothalamic-hypophysial axis as evidenced by the attainment of puberty nor did the treated gilts reach puberty earlier (Table 1).

\section{TABLE 1}

REPRODUCTIVE STATUS OF GILTS INJECTED WITH TESTOSTERONE PROPIONATE AND AUTOPSIED BETWEEN 150 AND 285 DAYS OF AGE

\begin{tabular}{l|c|c|c|c|c}
\hline \multirow{2}{*}{ Treatment } & \multirow{2}{*}{$\begin{array}{c}\text { No. of } \\
\text { animals }\end{array}$} & \multicolumn{2}{|c|}{ Oestrual } & \multicolumn{2}{|c}{ Non-oesirual } \\
\cline { 3 - 7 } & & No. & $\begin{array}{c}C L \\
\text { present }\end{array}$ & No. & $\begin{array}{c}\text { Immature uteri } \\
\text { and ovaries }\end{array}$ \\
\hline None & 25 & 15 & 15 & 10 & 10 \\
100 mg testosterone propionate & 25 & 21 & 21 & 4 & 4 \\
\hline
\end{tabular}

Ten of the control and four of the treated gilts that had not attained puberty at 285 days of age were killed. None of these gilts had corpora albicantia or corpora lutea in their ovaries, but all ovaries contained numerous follicles $\leqslant 1$ $\mathrm{mm}$ in diameter. They also had very small reproductive tracts and were classified as sexually immature.

Earlier research (Witschi \& Pfeiffer, 1935; Segal \& Johnson, 1959; Barraclough, 1961; Johnson, 1963; Swanson \& van der Werff ten Bosch, 1963) has shown that the hypothalamic-hypophysial axis in female rats can be altered by administering testosterone on the 5th day postnatally. A dose of $1.0 \mathrm{mg}$ testosterone propionate is considered to be adequate for a pup weighing $15 \mathrm{~g}$, thus $100 \mathrm{mg}$ should be adequate for a piglet weighing approximately $1225 \mathrm{~g}$ if both species react the same to dose level and the final differentiation of the axis has not already occurred before birth in swine.

Constant vaginal cornification or lack of ovulation and corpora lutea formation as observed by laparotomy may be used as an indication of modified hypothalamic-hypophysial axis in the puberal or mature rat. Vaginal cornification is not a good measurement of pro-oestrus in sows, thus laparotomy is the only way to determine lack of ovulation in those not exhibiting oestrus.

Laparotomies were not performed since more of the untreated than of the treated gilts had not exhibited oestrus by 285 days of age. The age of puberty has been observed to average 218 days in gilts of the same population although some may go beyond 300 days (Foote, Waldorf, Chapman, Self, Grummer \& Casida, 1956). 
Zimbelman (1964) has reported that gilts injected with testosterone propionate within $48 \mathrm{hr}$ of birth were not significantly affected as regards the average age of first oestrus and the intervals between oestrous cycles.

These results indicate that sows are not rendered anovulatory and sterile by testosterone propionate administration immediately after birth, as in the rat.

This investigation was supported in part by a Public Health Service Fellowship (1-F2-Gm-19,967-Ol) from the Division of General Medical Services, and the paper is published with the approval of the Director of the Wisconsin Agricultural Experiment Station.

One of us (F.W.S.) held a N.I.H. Fellowship during the experiment.

\section{REFERENCES}

Barraclovgh, C. A. (1961) Production of anovulatory sterile rats by single injections of testosterone propionate. Endocrinology, 68,62 .

Foote, W. G., Waldorf, D. P., Chapman, A. B., Self, H. L., Grummer, R. H. \& Gasida, L. E. (1956) Age at puberty of gilts produced by different systems of mating. J. Anim. Sci. 15, 959.

Johnson, D. C. (1963) Hypophyseal LH release in androgenized female rats after administration of sheep brain extracts. Endocrinology, 72, 832.

SEGAL, S. J. \& Johnson, D. C. (1959) Inductive influence of steroid hormones on the neural system; ovulation controlling mechanisms. Archs Anat. microsc, Morph. exp. 48, Suppl. 261.

Swanson, H. E. \& van der Werff Ten Bosch, J. J. (1963) Sex differences in growth of rats and their modification by a single injection of testosterone propionate shortly after birth. F. Endocr. 26, 197.

Witschi, E. \& PFEIfFer, C. A. (1935) The hormonal control of oestrus, ovulation and mating in the female rat. Anat. Rec. 64, 85 .

Zimbelman, R. G. (1964) Injection of steroids into newborn farm animals. (Abstract). F. Anim. Sci. 23, 1230 . 